
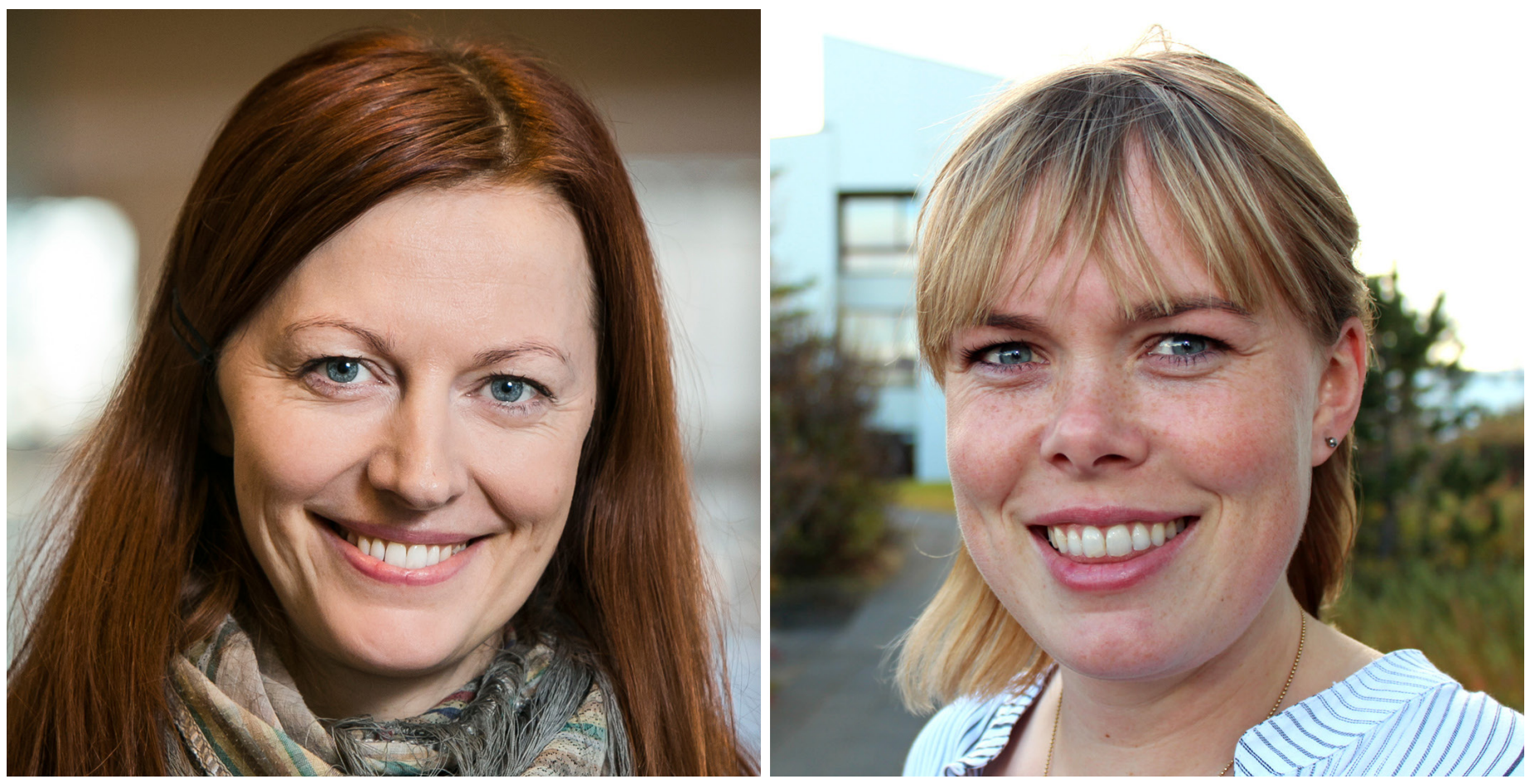

\title{
Móttaka nýnema á Verkfræði- og náttúruvísindasviði
}

\author{
Anna Helga Jónsdóttir, dósent við Raunvísindadeild á Verkfræði- og \\ náttúruvísindasviði og Sigdís Ágústsdóttir, kennslustjóri við Verkfræði- og \\ náttúruvísindasviơ Háskóla Íslands
}

\begin{abstract}
ársbyrjun 2018 fór kennslunefnd Verkfræði- og náttúruvísindasviðs ( $\mathrm{VoN})$ að huga að pví hvernig sviðið gæti tekið betur á móti nýnemum sínum. Búist var við fjölmennum og fjölbreyttum árgangi nýnema haustið 2018 vegna styttingar framhaldsskólans og pví var talið mikilvæegt að standa vel að móttökunni. Meginmarkmiðið var að auðvelda nemendum pau umskipti sem felast í að hefja nám á háskólastigi, annars vegar með pví að hjálpa peim að kljást við nýtt og krefjandi námsefni en hins vegar með pví að ýta undir tengslamyndun.
\end{abstract}

\section{Af hverju er mikilvægt að taka vel á móti nýnemum?}

Til að ná árangri í flestu námi sem boðið er upp á við VoN er mikilvægt að nemendur hafi góða pekkingu á framhaldsskólastærðfræði en sé hún ekki til staðar er hætt við að nemendur hætti í náminu (Anna Helga Jónsdóttir, Freyja Hreinsdóttir, Guðrún Geirsdóttir, Rögnvaldur G. Möller og Gunnar Stefánsson, 2013). Undanfarin ár hefur námsbraut í stærðfræði verið með stöðumat í stærðfræði fyrir nýnema VoN. Tilgangur stöðumatsins er að kanna pekkingu og færni nemenda í ýmsum grunnatriðum námsefnis framhaldsskóla við upphaf náms. Prófið gildir ekki til einkunnar í námskeiðum sviðsins heldur er ætlunin að nemendur og kennarar peirra sjái hvernig nemendur standa við upphaf náms. Árangur nemenda á prófinu er mjög misjafn en prófið hefur mjög gott forspárgildi um hvort nemendur ljúki skyldunámskeiðum í stærðfræði. Brottfall, svo og hlutfall nemenda sem ekki ná viðunandi árangri í pessum námskeiðum, er áhyggjuefni en undanfarin ár hefur aðeins um priðjungur nemenda sem skrá sig í námskeiðin lokið peim (Hrefna Hjartardóttir, 2016).

Umskipti (e. transition) nemenda frá framhaldsskóla í háskóla hafa verið rannsökuð víða og ljóst er að brottfall og slakur árangur í fyrsta árs námskeiðum í stærðfræðigreiningu við háskóla er alpjóðlegt vandamál (Hoyles, Newman og Noss, 2001). Töluvert hefur verið gert til að reyna að auðvelda nýnemum VoN pessi umskipti undanfarin ár. Nemendur hafa verið kynntir fyrir kennslukerfinu Tutor-web sem próað hefur verið á sviðinu undir handleiðslu Gunnars Stefánssonar prófessors í tölfræði. Tutor-web er opinn kennsluvefur (https://tutor-web.net/) í stærðfræði og tölfræði og eru púsundir fjölvalsæfinga aðgengilegar í kerfinu. Algrím sér um að úthluta æfingum til nemenda sem henta getu peirra hverju sinni og styður kerfið pví við einstaklingsmiðað nám. Pegar nemandi hefur svarað spurningu fær hann að sjá hvaða svarmöguleiki var sá rétti ásamt útskýringu á rétta svarinu. Nemandinn fær pví endurgjöf (e. feedback) á vinnu sína í rauntíma en rannsóknir hafa sýnt að pví fyrr sem nemendur fá endurgjöf á vinnu sína pví betur gagnast endurgjöfin peim (Cole og Todd, 2003). Auk pess að hafa aðgang að Tutor-web hefur nemendum verið boðið upp á stutta upprifjun á framhaldsskólastærðfræði við upphaf náms. Petta hefur mælst mjög vel fyrir meðal nemenda en yfir $90 \%$ peirra telja að kennslukerfið hafi hjálpað peim við upphaf náms (samkvæmt könnun meðal nýnema) og í rýnihópaviðtölum hafa nemendur lýst pví að 
kennslukerfið og önnur aðstoð sem peir fengu hafi skipt sköpum við upphaf náms. Í pessum viðtölum hafa nemendur kallað eftir aðgengi að vönduðu kennsluefni áður en námið hefst ásamt veigameiri upprifjun á grunnhugtökum stærðfræðinnar. Eldri nemar hafa einnig lýst mikilvægi pess að kynnast samnemendum sínum við upphaf náms og hvernig pað að vera hluti af hópi hafi hjálpað peim í náminu. Petta rímar við niðurstöður rannsóknar Magnúsar Pórs Torfasonar og Margrétar Sigrúnar Sigurðardóttur (2017) par sem vísbendingar sáust um að líkur á brotthvarfi minnkuðu hefði nemandi myndað tengsl við samnemendur sína.

Undanfarin tvö ár hafa deildir og námsbrautir getað sótt um svo kallaða B-leið í Kennslumálasjóð en pað eru stærri styrkir en áður fengust úr sjóðnum. Ákveðið var að Raunvísindadeild, sem sér um kennslu í stærðfræði á sviðinu, myndi sækja um styrk í sjóðinn fyrir verkefni sem sneri að bættri móttöku nýnema. Styrkur fékkst til að ráda fimm nemendur á sviðinu í sumarvinnu og voru pau Áshildur Jónsdóttir, Bjarni Hallgrímur Bjarnason, Guðný Halldórsdóttir, Gylfi Porsteinn Gunnlaugsson og Una Kamilla Steinsen ráðin.

\section{Umgjörðin - undirbúningur nýnemadaga.}

Undanfarin ár hefur nýnemum verið boðið upp á hálfs dags dagskrá par sem peir hafa fengið hinar ýmsu kynningar og verið boðnir velkomnir í nám á sviðinu. Að pessu sinni var ákveðið að setja saman dagskrá sem spannaði prjá daga par sem boðið yrði upp á ýmiss konar vinnustofur og kynningar ásamt hópefli. Auk pess yrði boðið upp á upprifjunarnámskeið í stærðfræði í fyrstu kennsluviku. Kynningarfundir fyrir nýnema yrðu einnig haldnir um sumarið og nýnemum boðið upp á að nýta sér kennsluefni á opnum vef til að undirbúa sig fyrir komandi nám.

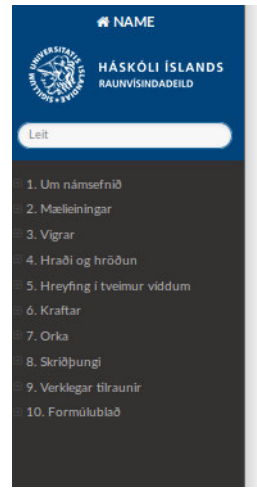

Docs = Undirbuningur i eodlisfredi, Háskoli íslands, haust 2018

View page source

Undirbúningur í eðlisfræði, Háskóli Íslands, haust 2018

-1. Um námsefnio

1.1. Hvad er ealisfracó

- 2. Mælieiningar

2.2. Önnur malikerf

- 3. Vigrar

3.1. Skilgreining

- 3.2. Aò liđà vigra

0 3.3. Einingarvigrar

0 3.4. Samlagning vigra

2. 3.5. Margfoldun viga

- 4. Hradi Hräri

- 4.2. Hröةou

๑ 4.3. Myndren tülkun

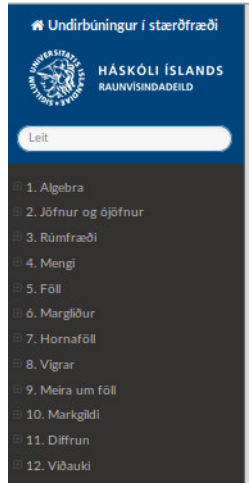

Docs s Undirbùningur i stærơfrææöi, Häskóli Íslands

View page source

Undirbúningur í stærðfræði, Háskóli Íslands

- 1. Algebra

1.1. Talnakerfi
0 1.2. Forgangsrōod

13.

1.4. Frumtölur

- 1.5. Brotareikningur

0 1.6. Deiling med afgangi

1.7. veldi og retur

- 2. Jofnur og ojoff
2.1. Jof fur

0 2.1. Jönur
0 2.2. Liỏun og păttun

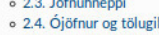

025.5 .

- 3. Rümfredi

- 3.1. Hnitakerfi

Mynd 2: Uppbygging námsefnis í stærðfræði og eðlisfræði.

Til að auðvelda upplýsingagjöf var vefsíða útbúin par sem öllum upplýsingum til nýnema var safnað saman á vefslóðinni: https://www. hi.is/nynemar_verkfraedi_og_natturuvisindasvids.

Dagskrá nýnemadaganna var gerð aðgengileg á vefsíðunni en hana má sjá á mynd 1.

Vefsíðunni var breytt nokkrum sinnum yfir sumarið og voru mismunandi atriði dregin fram. Í byrjun júní var póstur sendur á alla umsækjendur um nám á sviðinu, vefsíðan kynnt til sögunnar og peim boðið á kynningarfund bann 14. júní. Á fundinum var farið yfir pá aðstoð sem nýnemum stóð til boða yfir sumarið og við upphaf skólaárs. Kynningarfundir voru einnig haldnir 9. og 10. ágúst (nemendur gátu mætt hvorn daginn sem var) par sem nemendur gátu fengið aðstoð í notkun Tutor-web kerfisins. Pessir kynningarfundir voru vel sóttir og mættu um 200 nemendur í júní og álíka fjöldi í ágúst. Nemendur spurðu margs á pessum fundum og skemmtilegar umræður áttu sér stað.

\section{Námsefnisgerð}

Benedikt Steinar Magnússon, lektor í stærðfræði, hefur undanfarin ár próað kerfi par sem má með einföldu móti útbúa rafrænt

\section{Móttaka nýnema - dagskrá}

\begin{tabular}{|c|c|c|c|}
\hline Tími & Miðvikudagur 22. ágúst & Fimmtudagur 23. ágúst & Föstudagur 24. ágúst \\
\hline \multirow[t]{2}{*}{ 09:00 - 12:00 } & Vinnustofa í staerðfraði & Kynning á tölvunarfræeði & Móttaka nýnema \\
\hline & $\begin{array}{l}\text { Farið yfir grunnatriði í } \\
\text { stærðfræði. Námsefni á } \\
\text { edbook.hi.is }\end{array}$ & $\begin{array}{c}\text { Reiknirit - gervigreind - } \\
\text { forritun - hugbúnaðarverkfræði }\end{array}$ & 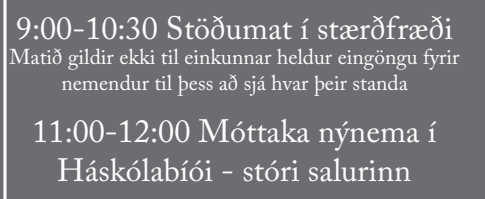 \\
\hline $12: 00-13: 00$ & Hádegishlé & Hádegishlé & Grill fyrir nýnema \\
\hline \multirow[t]{2}{*}{$13: 00-16: 00$} & Vinnustofa í eðlisfrææði & Kynning frá námsleið & Hópefli með nemendafélögum \\
\hline & $\begin{array}{c}\text { Farið yfir grunnatriði í } \\
\text { eðlisfræði. Námsefni á } \\
\text { edbook.hi.is }\end{array}$ & $\begin{array}{c}\text { Nemendur kynnast sinni } \\
\text { námsgrein, kennurum peirrar } \\
\text { námsgreinar og samnemendum }\end{array}$ & $\begin{array}{c}\text { Nýnemum er boðið í grill eftir } \\
\text { móttöku í Háskólabiói og í } \\
\text { framhaldinu verður skemmtidag- } \\
\text { skrá sem nemendafélög sviðsins } \\
\text { skipuleggja }\end{array}$ \\
\hline
\end{tabular}

Mynd 1: Dagskrá nýnemadaga 22. - 24. ágúst 2018 í Háskóla Íslands 


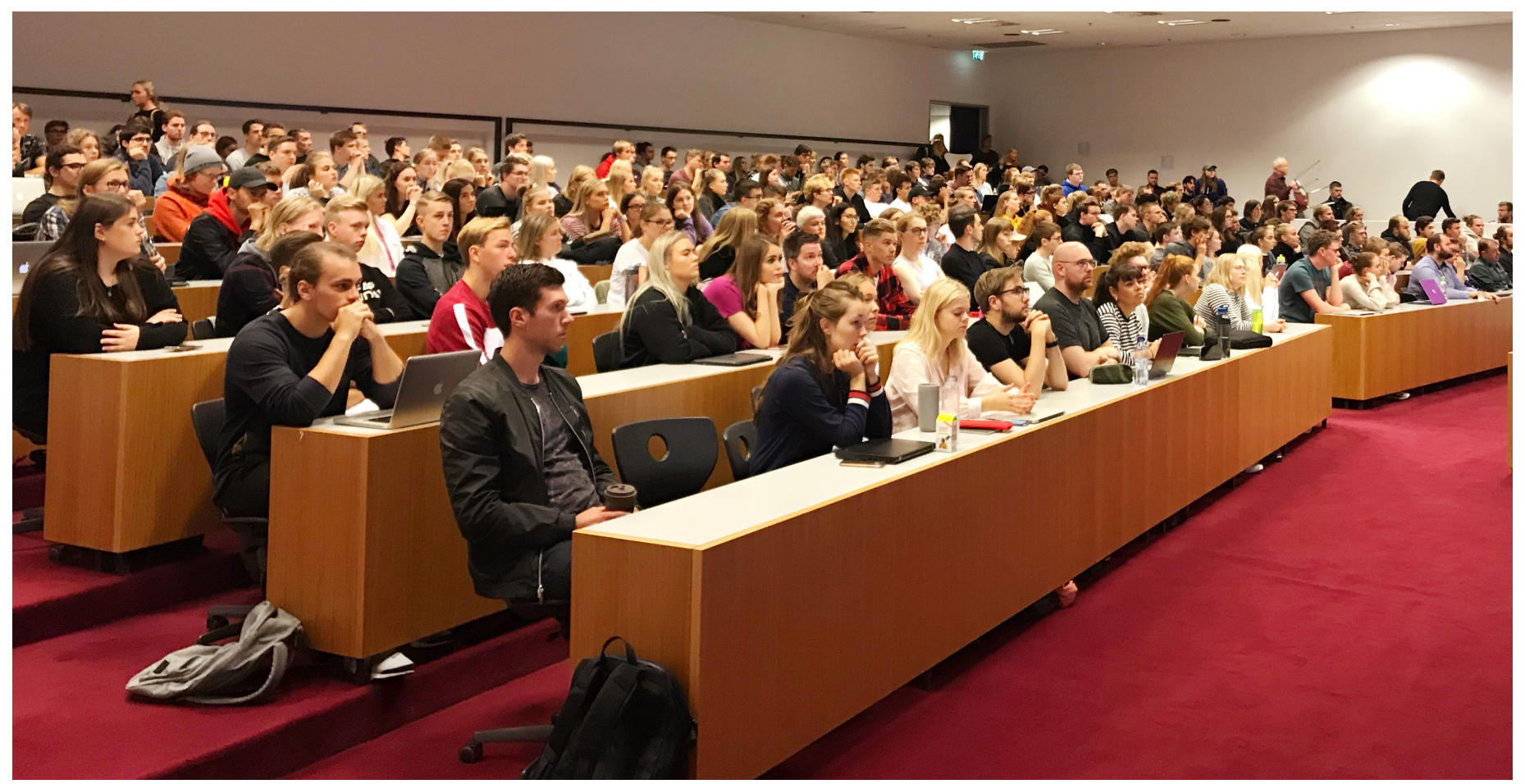

Mynd 3: Vinnustofa í tölvunarfræði.

og gagnvirkt kennsluefni sem er aðgengilegt í vefsíðusniði, pdf-skjali og rafbókarsniði. Kerfið kallast Edbook og er aðgengilegt hér: http://edbook.hi.is/. Sumarið 2017 var námsefni í framhaldsskólastærðfræði, sem upphaflega var skrifað af Ragnari Sigurðssyni prófessor í stærðfræði, en margir hafa komið að síðan, fært inn í kerfið. Sumarstarfsmennirnir unnu áfram með efnið og má sjá afraksturinn hér: http://edbook.hi.is/undirbuningur_stae/

Sumarstarfmennirnir létu ekki staðar numið par heldur útbjuggu peir einnig upprifjunarefni í eðlisfræði í kerfinu sem sjá má hér: http://edbook.hi.is/undirbuningur_ed1/

Á mynd 2 má sjá uppbyggingu námsefnisins. Mikil ánægja var með efnið meðal nýnemanna en pað nýtist ekki aðeins nemendum $\mathrm{VoN}_{\mathrm{N}}$ heldur getur pað nýst öllum nýnemum HÍ sem ætla í nám par sem nemendur purfa að kunna góð skil á framhaldsskólastærðfræði eða eðlisfræði.

\section{Vinnustofur}

Eins og fram hefur komið á stór hluti nemenda VoN í erfiðleikum með stærðfræði við upphaf náms og sömu sögu er að segja um eðlisfræði og tölvunarfræði. Pví var ákveðið að bjóða upp á stuttar vinnustofur í pessum premur greinum á nýnemadögunum. Að auki var ákveðið að hver námsbraut héldi vinnustofu fyrir sína nemendur. Hver vinnustofa yrði tvær til prjár klukkustundir og pví ekki raunhæft að fara yfir mikið efni á pessum tíma. Pví var ákveðið að nýta vinnustofurnar í stærðfræði og eðlisfræði fyrst og fremst til að segja nemendum frá pví hvernig greinarnar nýtast í hinum ýmsu fögum og í hópefli. Sumarstarfsmennirnir sáu alfarið um að skipu- leggja og halda vinnustofurnar og fengu peir aðstoð frá nokkrum samnemendum sínum meðan á peim stóð.

Par sem fæstir nýnemar hafa kynnst tölvunarfræði í framhaldsskólum var markmiðið með peirri vinnustofu að kynna hinar ýmsu hliðar tölvunarfræðinnar fyrir nemendum. Kennarar námsbrautar í tölvunarfræði sáu um pá vinnustofu. Um 400 nýnemar sóttu vinnustofuna í stærðfræði en eitthvað færri hinar vinnustofurnar tvær en eðlisfræði og tölvunarfræði eru ekki hluti af öllu námi á sviðinu.

Algengt er að nemendur sæki undirstöðunámskeið á fyrsta misseri sínu í náminu. Sem dæmi má nefna sækir hinn dæmigerði verkfræðinemi meðal annars námskeið í stærðfræði, eðlisfræði og tölvunarfræði á fyrsta misseri. Til að nemendur gætu hitt sem flesta af kennurum námsbrautarinnar sem peir ætluðu í nám við í byrjun náms var ákveðið að halda vinnustofur í öllum námsbrautum á nýnemadögunum. Par fengu nemendur smjörpefinn af pví sem koma skyldi í náminu, kynntust kennurum námsbrautarinnar og öðrum samnemendum sínum.

\section{Móttaka og hópefli med nemendafélögum}

Að morgni lokadags nýnemadaga preyttu nýnemar stöðumat í stærðfræði en að pví loknu var móttaka í Háskólabíói. Rektor, Jón Atli Benediktsson, og sviðsforseti, Sigurður Magnús Garðarsson, buðu nýnema velkomna og kynnti sviðsforseti hina ýmsu starfsemi og pjónustu sviðsins. Jónína Ólafsdóttir Kárdal kynnti starfsemi Náms- og starfsrádgjafar HÍ og formaður Stúdentaráðs, Elísabet Brynjarsdóttir og Númi Sveinsson, Sviðsráði VoN, sögðu frá starfsemi ráðanna. Að lokum sagði Sylvía Kristín Ólafsdóttir, forstöðumaður hjá Icelandair og fyrrum nemandi sviðsins, nýnemum frá lífinu að loknu námi við sviðið. Að móttökunni lokinni var grillað í blíðskaparveðri og nemendum skipt í hópa eftir nemendafélögum. Við tók dagskrá sem nemendafélögin höffu skipulagt par sem nýnemar fóru meðal annars í ratleik með eldri nemendum.

\section{Undirbúningsnámskeið í stærðfræði}

Eins og fram kom hér að framan hefur stöðumat í stærðfræði verið lagt fyrir nýnema VoN við upphaf misseris undanfarin ár. Árangur nemenda á prófinu er mjög misjafn og æskilegt væri að geta boðið peim sem standa höllum fæti upp á aðstoð við upphaf misserisins. Pví var ákveðið að halda upprifjunarnámskeið á framhaldsskólastærðfræði í fyrstu kennsluviku. Dæmatímar og verkleg kennsla hefst ekki fyrr en í annarri kennsluviku og pví eru nemendur sviðsins ekki í tímum eftir hádegi fyrstu vikuna. Nemendur preyttu stöðumatið föstudaginn 24. ágúst og gátu peir séð árangur sinn í Uglu næsta dag. Nemendur, sem ekki náðu góðum árangri í stöðumatinu, voru sérstaklega hvattir til að nýta sér upprifjunarnámskeiðið og voru pátttakendur um 150 talsins. Sumarstarfsmennirnir sáu alfarið um námskeiðið með aðstoð nokkurra samnemenda sinna og var mikil áhersla lögð á virka pátttöku nýnemanna. Рað var gert með aðstoð Socrativeforritsins (http://socrative.com) sem notað hefur verið með mjög góðum árangri í nokkrum námskeiðum á sviðinu. Með forritinu getur kennari beðið nemendur að leysa ákveðin verkefni og fylgst með hvernig 


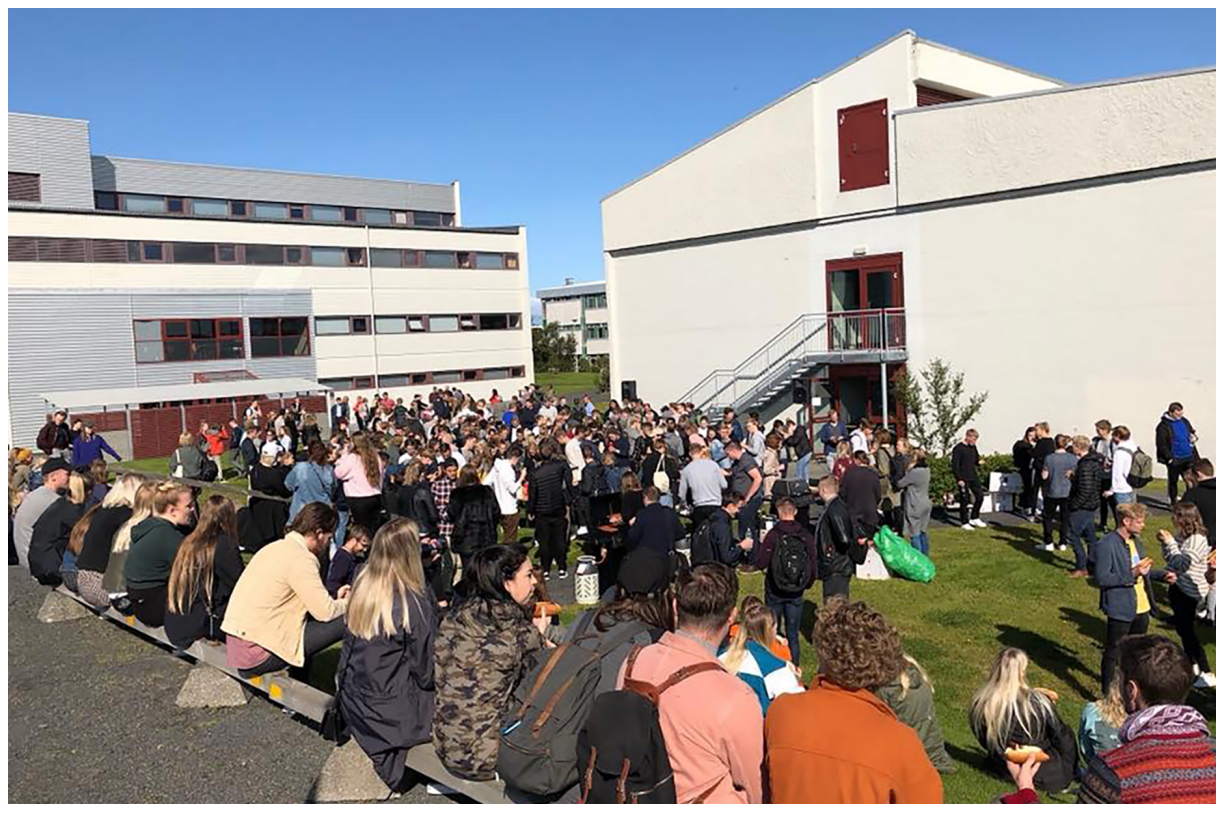

Mynd 4: Grillveisla á nýnemadögum.

gengur í rauntíma. Kennari getur pá séð hvaða efni nemendur hafa náð tökum á og hvaða efni parf að fara betur í. Við val á efnistökum upprifjunarnámskeiðsins var stuðst við niðurstöður stöðumatsins undanfarin ár og var megináhersla lögð á algebru og fallahugtakið ásamt nokkrum öðrum lykilhugtökum.

\section{Hvernig tókst til og hvernig nýtist verkefnið áfram?}

Pað var fljótt ljóst að sumarstarfsmennirnir bjuggu yfir mörgum góðum hugmyndum og voru mun betur til pess fallnir að skipuleggja dagskrá fyrir nýnema en kennarar sviðsins.

Peir stóðu sig frábærlega allt sumarið í undirbúningsvinnunni og var sérstaklega gaman að fylgjast með framkvæmdinni hjá peim á sjálfum nýnemadögunum. Auk pess að skipuleggja nýnemadagana og vinna í kennsluefni tóku peir saman ýmiss konar fróðleik fyrir nýnema og útbjuggu glæsilegt kynningarmyndband um byggingar skólans. Рað vildi svo heppilega til að einn sumarstarfsmaðurinn, Bjarni Hallgrímur, er sérfræðingur í myndbandagerð og sá hann um gerð myndbandsins sem sjá

Samstarf

\section{Heimsókn frá Háskólanum í Tromsö}

\section{Ásta Bryndís Schram, lektor og kenns/upróunarstjóri á Heilbrigð̋isvís indasviði og kenns/uráđgjafi við Kennslumið̌stöð Háskóla Íslands}

Starfsfólk Kennslumiððstöðvar Háskóla Íslands á góða samstarfsfélaga við Háskólann í Tromsö í Noregi. Pessi kynni mynduð̌ust í gegnum samstarfsnetið Nordic-Baltic Network. Pær Anita Iversen, Siri Skommesvik, Rigmor Furu og Nanna Hauksdóttir, allar starfandi á Kennslu mið̌stöð Heilbrigð̌isvisindasvið̌s Háskólans í Tromsö (n. Senter for helsefaglig pedagogisk utvikling), sóttu okkur heim og kynntu sér meðal annars starfsemi Kennslumið̌stöðvarinnar. Kennslupróun er peirra ær og kýr, ekki síst efling á pverfræðilegu samstarfi og pverfræðilegu námi á Heilbrigðisvisindasviðði. Nanna Hauksdóttir er forkólfur að myndun norræns nets um pverfræðilegt nám og samstarf - NIPNET - og við hlökkum til frekara samstarfs.

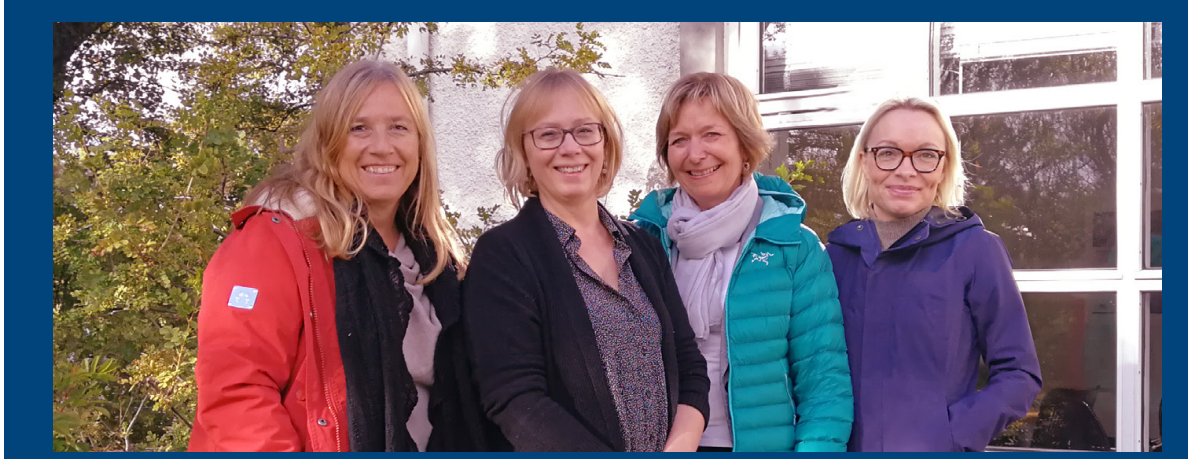

Ásta Bryndís Schram er hér í góðum hópi Tromsö kvenna. Ljósmynd: Elva Björg Einarsdóttir. má hér: https://www.youtube.com/watch?time_continue $=1 \& v=3$ otiN36o8r4 og á vefsíðu nýnemadaganna.

Á stöðumatinu í stærðfræði voru nemendur spurðir um upplifun sína af nýnemadögunum. Um 80\% nýnema sem tóku pátt í nýnemadögunum sögðust hafa haft gagn og/eða gaman af vinnustofunum í stærðfræði, eðlisfræði og tölvunarfræði og 99\% nýnema sögðust hafa haft gagn og/eða gaman af námsbrautarvinnustofunum. Auk spurninganna í stöðumatinu var spurningalisti sendur til nýnema par sem peim gafst kostur á að svara opnum spurningum um upplifun sína af nýnemadögunum. Sem dæmi um athugasemdir sem komu fram eru að gott hafi verið að kynnast samnemendum sínum og kennurum við upphaf náms, vinnustofurnar hafi komið peim í gírinn og nýnemadagarnir hafi losað um stressið sem fylgir pví að byrja í nýju námi. Рað kom einhverjum á óvart að í vinnustofunum hafi verið meira lagt upp úr hópefli en kennslu, einhverjum fannst yfirferðin of hröð en öðrum of hæg.

Eftir sumarið liggur eftir mikið af kennsluefni, kynningarefni og reynsla sem mun nýtast áfram við móttöku nýnema. Ákveðið hefur verið að búa til námskeið í edX Edge sem kennarar Hí hafa nú aðgang að eftir að skólinn gerðist aðili að edX í nóvember 2017. Pannig mætti hugsa sér að pegar nýnemi er sampykktur inn í nám á sviðinu sé hann skráður í námskeiðið og hafi pannig aðgang að námsefni í stærðfræði og eðlisfræði auk ýmiss konar kynningarefnis sem mun vonandi auðvelda nýnemum að hefja nám við Verkfræði- og náttúruvísindasvið um komandi ár.

\section{Heimildir}

Anna Helga Jónsdóttir, Freyja Hreinsdóttir, Guðrún Geirsdóttir, Rögnvaldur G. Möller og Gunnar Stefánsson. (2013). Könnunarpróf nýnema í stærðfræði við Háskóla Íslands. Tímarit um menntarannsóknir, 10(1), 11-28. Sótt af https:// timarit.is/view_page_init.jsp?pageId=6689396

Cole, R. S. og Todd, J. B. (2003). Effects of web-based multimedia homework with immediate rich feedback on student learning in general chemistry. Journal of Chemical Education, 80(11), 1338-1343. https://doi.org/10.1021/ ed080p1338

Hoyles, C., Newman, K. og Noss, R. (2001). Changing patterns of transition from school to university mathematics. International Journal of Mathematical Education in Science and Technology, 32(6), 829-845. https://doi. org/10.1080/00207390110067635

Hrefna Hjartardóttir (2016). Brottfall úr námskeidi i stardfradigreiningu metið med lifunargreiningu (meistararitgerð). Sótt af https://hdl.handle. net/1946/26201

Magnús Pór Torfason og Margrét Sigurðardóttir. (2017). Tengslanet nemenda og brottfall úr háskólanámi. Netla - Veftimarit um uppeldi og menntun. Sótt af http://netla.hi.is/greinar/2017/ ryn/07.pdf 